\title{
ENGLISH AS A TOOL FOR CROSS-CULTURAL COMMUNICATION
}

\section{O INGLES COMO UMA FERRAMENTA PARA A COMUNICAÇÃO INTERCULTURAL}

\section{EL INGLÉS COMO HERRAMIENTA DE COMUNICACIÓN INTERCULTURAL}

\author{
Diana Rustamovna SABIROVA ${ }^{1}$ \\ Regina Rafael'yevna KHANIPOVA ${ }^{2}$ \\ Rimma Raisovna SAGITOVA ${ }^{3}$
}

\begin{abstract}
The ability to speak one language is considered insufficient for successful career development. It is believed that speaking more than one language can deliver the economic growth of the country. Integration and globalization in education set new educational standards for future professionals. The study is relevant due to the significance of the English language in various spheres of activity. The development of the intercultural communicative competence is the main objective of educational institutions all over the world and international organizations such as the United Nations Educational, Scientific and Cultural Organization (UNESCO) and the Organization for Economic Co-operation and Development (OECD). English as an international language is considered by the author as a tool for cross-cultural communication. The main aim of the research work is to identify the concept of cross-cultural communication as a part of intercultural communication competence. The authors reveal potential challenges in language learning and give different approaches to successful language acquisition. The case study of the USA as one of the multi-ethnic countries in the world deserves examining. The system of education in the USA takes leading positions in the matter of modernization and reformation. Fundamental principals in learning English as a foreign language/ English as a second language reflect the well-organized system ensuring the development of tolerance, respect for the representatives of different ethnic groups, their cultures, beliefs and values, thus, providing efficient intercultural communication.
\end{abstract}

KEYWORDS: Communication. Intercultural communication. Critical thinking. English as an international language. Linguistics.

RESUMO: A habilidade de falar um idioma é considerada insuficiente para o desenvolvimento de uma carreira de sucesso. Acredita-se que falar mais de um idioma pode proporcionar o crescimento econômico do país. A integração e a globalização na educação definem novos padrões educacionais para os futuros profissionais. O estudo é relevante devido à importância da língua inglesa em várias esferas de atividade. $O$ desenvolvimento da competência comunicativa intercultural é o principal objetivo das instituições de ensino de todo o mundo e

${ }^{1}$ Kazan (Volga Region) Federal University (KPFU), Kazan - Russia. Associate Professor and Head of Higher School of Foreign Languages and Translation Studies. Doctor of Education. ORCID: https://orcid.org/0000-00027657-5260. E-mail: dianasab@mail.ru

${ }^{2}$ Kazan (Volga Region) Federal University (KPFU), Kazan - Russia. Lecturer of the Higher School of Foreign Languages and Translation Studies. ORCID: https://orcid.org/0000-0003-0942-9009. E-mail: regina-90@inbox.ru ${ }^{3}$ Kazan (Volga Region) Federal University (KPFU), Kazan - Russia. Associate Professor of the Department of European Languages and Cultures. Candidate of Pedagogical Science. ORCID: https://orcid.org/0000-0001-78223819. E-mail: sag-rimma@yandex.ru 
de organizações internacionais como a Organização das Nações Unidas para a Educação, a Ciência e a Cultura (UNESCO) e a Organização para a Cooperação e Desenvolvimento Econômico (OCDE). O inglês como língua internacional é considerado pelo autor como uma ferramenta de comunicação intercultural. O principal objetivo do trabalho de pesquisa é identificar o conceito de comunicação intercultural como parte da competência de comunicação intercultural. Os autores revelam desafios potenciais na aprendizagem de línguas e oferecem diferentes abordagens para a aquisição bem-sucedida da língua. O estudo de caso dos EUA como um dos países multiétnicos do mundo merece ser examinado. O sistema de educação nos EUA assume posições de liderança em matéria de modernização e reforma. Os princípios fundamentais da aprendizagem do Inglês como língua estrangeira / Inglês como segunda língua refletem o sistema bem-organizado que garante o desenvolvimento da tolerância, respeito pelos representantes dos diferentes grupos étnicos, suas culturas, crenças e valores, proporcionando assim uma comunicação intercultural eficiente.

PALAVRAS-CHAVE: Comunicação. Comunicação intercultural. Pensamento crítico. Inglês como língua internacional. Linguística.

RESUMEN: La capacidad de hablar un idioma se considera insuficiente para el desarrollo profesional exitoso. Se cree que hablar más de un idioma puede generar crecimiento económico del país. La integración y la globalización en la educación establecen nuevos estándares educativos para los futuros profesionales. El estudio es relevante por la trascendencia del idioma inglés en diversos ámbitos de actividad. El desarrollo de la competencia comunicativa intercultural es el principal objetivo de las instituciones educativas de todo el mundo y de organismos internacionales como la Organización de las Naciones Unidas para la Educación, la Ciencia y la Cultura (UNESCO) y la Organización para la Cooperación y el Desarrollo Económicos $(O C D E)$. El inglés como idioma internacional es considerado por el autor como una herramienta para la comunicación intercultural. El objetivo principal del trabajo de investigación es identificar el concepto de comunicación intercultural como parte de la competencia de comunicación intercultural. Los autores revelan desafios potenciales en el aprendizaje de idiomas y brindan diferentes enfoques para una adquisición exitosa del idioma. El estudio de caso de Estados Unidos como uno de los países multiétnicos del mundo merece ser examinado. El sistema educativo de los Estados Unidos ocupa posiciones de liderazgo en materia de modernización y reforma. Los principios fundamentales del aprendizaje de inglés como lengua extranjera / inglés como segunda lengua reflejan un sistema bien organizado que garantiza el desarrollo de la tolerancia, el respeto por los representantes de los diferentes grupos étnicos, sus culturas, creencias y valores, proporcionando así una comunicación intercultural eficaz.

PALABRAS CLAVE: La comunicación. Comunicación intercultural. Pensamiento crítico. El inglés como lengua internacional. Lingüística.

\section{Introduction}

Language as a means of communication, as well as an effective tool for education, helps a person to gain knowledge in different areas of study. The image of a successful person of the XXI century is based on multitasking. Every candidate is supposed to show the ability to hold 
communication with the representatives of other countries. Today, one of the urgent problems, in the era of globalization and integration processes in education, is the development of intercultural foreign language communication competence (SABIROVA; KHANIPOVA, 2019).

There are different contemporary ways to deal with showing English as an unknown dialect. They are: English as a most widely used language (ELF) - mindful teaching method (J. Bayurt, N. Sayfakis), worldwide Englishes language instructing (GELT) (N.J. Galloway), showing English as an International Language (A. Matsuda, S.L. McKay), World Englisheseducated English Language Teaching (A. Matsuda). A binding together component of all advanced methodologies is showing an assortment of English language lingos spoken around the planet, conversely with the customary way to deal with showing English as an unknown dialect. The advocates of these methodologies think of it as erroneous to show British or American English, in spite of the way that most of English speakers comes from these nations. As they would see it, understudies ought to gain proficiency with the English language tongues spoken in the nation of the English as a second language speaker (MATSUDA, 2017).

The USA is a country with a global populace. In $2000-2017$, the number of inhabitants in the nation expanded by $15 \%$ from 282,2 million individuals to 325,3 million individuals. The population consists of different ethnic groups: White, Black, Hispanic, Asian, American Indians and Alaska Natives, Pacific Islanders, representatives of two or more races and others. Coexistence of diverse nationalities is impossible without tolerance and respect for people and their culture. The English language acts as the link for successful communication. That is why the USA as a multinational and multicultural country is worth studying.

\section{Methods}

Essential hypothetical chiefs of our investigation were set up with the assistance of the examination of the works by Byram (1994), Byrnes (2002), Cummins and Griffin (2012), Fasset and Warren (2006), Jackson, Guzman and Ramos (2010), Kearney (20150, Matsuda (2017), Sobré-Denton (2013) and others, which are devoted to the study of effective English as a foreign language learning methods.

We based our study on the following research methods:

- A graphic strategy for perception and order of the explored material;

- A system arranged examination of writing just as government and non-government official papers, codes, plans and reports on the issue. 


\section{Results and discussion}

\section{Challenges of learning the language through culture}

As the main objective in teaching English as a foreign language is the development of intercultural communication competence, a teacher faces the challenges that prevent learners from mastering the language easily.

Kearney (20150 speaks of the important role of culture in foreign language learning and defines the main challenges, which can be referred to any foreign language learning as well as English. They are the challenges of:

- $\quad$ Integrating language and culture;

- Defining society;

- Undoing the treatment of culture in essentializing or reductionist ways;

- Getting past social 'realities' to recognize intricacy and inconsistency in social information and experience;

- Moving away from originations of culture as procedural information and envisioning jobs that are more powerful for students as language clients;

- $\quad$ Specifying interpretive cycles engaged with intercultural learning;

- Connecting and furthermore recognizing the individual and individual from the social and shared;

- $\quad$ Overcoming surface correlation;

- $\quad$ Theorizing and actualizing more extensive importance making approaches in multilingual training;

- More profoundly captivating subjectivities in culture in multilingual schooling.

Scientists support the idea of learning language through culture. Some of them consider culture as a '5th skill' in addition to reading, writing, speaking and listening (DAMEN, 1987), others use the concept 'languaculture' to convey the meaning of integration of culture and language (BLUM, 1996).

Notwithstanding, the scientists cannot come to understanding for characterizing what 'culture' is. Sscholars recognize 'high' or 'enormous C culture' and 'low' or 'minimal c culture'. From one viewpoint, the idea of 'culture' incorporates the investigation of writing, workmanship, reasoning of the nation of the unknown dialect (BYRNES, 2002; SWAFFER; ARENS, 2005). Then again, the investigation of the 'way of life' of the nation of the unknown dialect is considered as a colleague with the everyday real factors of life of local speakers. Thus, 
Byram (1994) identifies one of the educational goals that every foreign language teacher should set. It is to raise the interest and motivation of students.

\section{Intercultural communication competence development}

Present day ways to deal with encouraging an unknown dialect in the United States include the investigation of culture as a necessary segment of the objective language. The teacher, in this case, is the tool for the implementation of the intercultural approach to learning.

Weaver (1986) identifies three levels of culture, depicting them in the form of an iceberg, on top of which is the surface culture. We can sense it, recognize it - it is a visible component of culture. It includes works of art, traditions and customs of the nation. The next level in the iceberg structure is the deep culture or the internal culture, which involves the development of spiritual values and believes, which are kept by different nationalities: rules of conduct, contextual conversational patterns etc. The deep culture consists of two sublevels: unspoken influences (courtesy, conversational patterns, facial expressions, conduct, concept of time, etc.) and unconscious influences (body language, values and thought patterns, attitude to the environment, etc.). Only the first component is included into the programme of the English language and culture study in schools.

One of the arguable questions of scientists and linguists today is the development of the intercultural communication competence. Gay (2010), J. Hoover (2008) and Tatum (1997), in independent studies, consider it to be difficult to do it, as the native population of the country of the target language imposes its deep-rooted values and strong traditions.

English as a foreign language is taught at the US schools via a great number of programmes. They are Transitional Bilingual Programmes (Early-Exit Transitional Bilingual Programme or Late-Exit Transitional Bilingual Programme) and Dual Language Programmes: Developmental or Maintenance Dual Language, Two-Way Immersion Programme.

US scholars Finehauer and Howard (2014) conducted research that showed that Dual language programmes are not focused on the development of intercultural communication competence. The object of the programme is the development of the bilingualism or the development of the English language communicative skills. This fact is disputable as it contradicts with the main goal of the English language education that is to develop student's intercultural communicative competence.

Most of the researchers argue that teacher's awareness of the cultural values of the target language plays the major role in learning and teaching English as a Foreign language. Teacher's 
intercultural competence contributes to a better understanding of cultural values among students, raises student's motivation for learning a foreign language, improves teaching skills, provides opportunities for practice-based learning (SABIROVA et al., 2019; ABROSIMOVA; KONDRATEVA, 2018; ABDULLINA; AGEEVA; GABDREEVA, 2019)

Hanley (1999), Hays (2008) and Jackson, Guzman, and Ramos (2010), came to the conclusion that the development of intercultural communication competence of a teacher is possible only through the awareness culture of the native language. Foreign language culture is better comprehended when it has common features with the culture of the native language.

Such activities as creating the 'linguistic portrait' that involves the analysis of the history of learning the language in the life of a teacher, the analysis of the methods of teaching the language in the school where teachers studied as students, the analysis of the situational context of the language use, etc. and 'photo story' is a project work, which helps to develop the linguistic and socio-cultural awareness of future teachers. These methods are practiced at California State University. The main aim of these practices is to develop teachers critical thinking.

Critical thinking is implemented in the teacher training activities as well as in students learning ones. It is based on the experience and reflection. It helps to raise understanding, respect, tolerance for the values of other cultures.

Thus, Cummins and Griffin (2012) argue that critical intercultural communication education helps to overcome oppressive relations between students and organize the learning process in accordance with students interests. Fasset and Warren (2006) developed a theory of critical education based on a communicative approach. According to the scholars, the components of the above-mentioned approach is culture, a sense of belonging to a certain nation and self-confidence, awareness of the importance of a target language, communication and learning, the desire to change the learning system through communication and learning.

For a long time, it was believed that intercultural learning teaches the ways to overcome differences by assimilation with a dominant culture. However, Martin and Nakayama (1999), using a dialectical approach to intercultural communication stated that experience-based learning helps to study the language from different perspectives. Sorrells (2013) noted, a critical intercultural communication education contributes to the development of the tolerance in students and emphasizes the important role of a teacher in class.

Cosmopolitan pedagogy is one of the forms of critical intercultural education. The concept was first used by Sobré-Denton and Bardhan. The aim of it is to educate the global citizen (SOBRÉ-DENTON; BARDHAN, 2013). This form of critical intercultural education is 
based on a cyclic model of learning and is defined by three concepts: desire, memory and dialogue. Every student is supposed to have a desire to develop, reflect over the wrong conduct in the past (memory) and share his/her understanding of the world with other students in the form of a dialogue, i.e., the world is perceived through culture of different nations.

The roles of a teacher and a student are mixed. Teachers and students can both learn and study. Here are the examples of the implementation of critical intercultural communication education in the USA.

Hi-Chicago programme is designed on the basis of state educational institutions, the International Baccalaureate Programme and the social movement Buildon.org. The programme is aimed at teaching ethnic minorities the English language and culture. The programme includes the basic course of intercultural communication. The project work of the course is to interview the natives the cultural values of the target language country. Thus, students learn the English language culture through the values of their own culture.

Social networking sites Space2cre8 and Hi -USA is targeted at teaching teenagers English as a foreign language. The working language of the site is English. Students in grades 7-11 can communicate, share media files, hold discussions on various topics, and write a blog post.

\section{Summary}

In order to implement intercultural communication approach to teaching the English language in the USA, educational institutions face with the tasks that lead to successful intercultural communication. They are:

- to implement diverse teaching methods and techniques to overcome various barriers of intercultural communication;

- to provide a shift from an informative content-based teaching strategies in teaching English as a Foreign Language to a communicative developmental or practice-oriented strategy;

- to ensure the native and the English language and culture integration;

- to expand students vocabulary and use case-based learning English that contributes to the development of critical thinking;

- to increase students and teachers cultural awareness that lead to the effective development of intercultural communication competence. 


\section{Conclusion}

In conclusion, we would like to say that the development of intercultural communication competence is becoming an essential component of any type of educational programme, providing access to world scientific, technological and humanitarian achievements and contributing to the development of intellectual potential of every student.

ACKNOWLEDGMENTS: The work is performed by the Russian Government Program of Competitive Growth of Kazan Federal University.

\section{REFERENCES}

ABDULLINA, L. R.; AGEEVA, A. V.; GABDREEVA. N. V. Using the Flipped classroom model in the teaching of the theoretical disciplines (French language) at the university. XLinguae, v. 12, n. 1XL, p. 161-169, 2019.

ABROSIMOVA, G. A.; KONDRATEVA. I. G. Strategies for effective foreign language perception. Kazan Linguistic Journal, v. 1, n. 4, p. 72-81, 2018.

BLUM, S. D. Language shock: understanding the culture of conversation. Journal of Linguistic Anthropology, v. 6, n. 1, p. 105-107, 1996.

BYRAM, M. Teaching-and-learning language-and-culture. Clevedon: Multilingual Matters, 1994.

BYRNES, H. The cultural turn in foreign language departments: challenges and opportunity. Profession, p. 114-129, 2002.

CUMMINS, M. W. GRIFFIN, R. A. Critical race theory and critical communication pedagogy: articulating pedagogy as an act of love from black male perspectives. Liminalities: A Journal of Performance Studies, v. 8, n. 5, p. 85-106, 2012.

DAMEN, L. Culture learning: the fifth demention in the language classroom. Reading, MA: Addison-Wesley Publishing Company, 1987.

FASSETT, D. L.; WARREN. J. T. Critical communication pedagogy. Thousand Oaks, CA: Sage, 2006.

FINEHAUER, E.; HOWARD. E. Attending to the third goal: cross-cultural competence and identity development in two-way immersion programs. Journal of Immersion and ContentBased Language Education, v. 2, n. 2, p. 257-272, 2014.

GAY, G. Culturally responsive teaching: theory, research and practice. 2. ed. New York: Teachers College Press, 2010. 
HANLEY, J. Beyond the tip of the iceberg: Five stages toward cultural competence. Today's Youth: The Community Circle of Caring Journal, v. 3, n. 2, p. 9-12, 1999.

HAYS, D. G. Assessing multicultural competence in counselor trainees: A review of instrumentation and future directions. Journal of Counseling and Development, v. 2, n. 1, p. 95-101, 2008.

HOOVER, J. J. et al. Methods for teaching cultural linguistically diverse exceptional learners. Newark, NJ: Pearson Education, 2008.

JACKSON, L. G.; GUZMAN, S. B.; RAMOS, G. Learning a borderland professional identity. Counterpoints, Teaching Bilingual/Bicultural Children: Teachers Talk about Language and Learning, v. 37, n. 1, p. 29-37, 2010.

KEARNEY, E. Intercultural learning in modern language education: expanding meaningmaking potential. Bristol: Multilingual Matters, 2015. 216 p. DOI:

doi.org/10.21832/9781783094684

MARTIN, J. N.; NAKAYAMA, T. K. thinking dialectically about culture and communication. Communication Theory, v. 9, n. 1, p. 125, 1999.

MATSUDA, A. Preparing teachers to teach english as an international language. Bristol: Multilingual Matters, 2017. 256 p. DOI: doi.org/10.21832/9781783097036

SABIROVA, D. R. et al. Comprehension of the English National Character in Building Professional Linguistic Culture. Journal of Educational and Social Research, v. 9, n. 3, p. 101-106, 2019.

SABIROVA, D. R.; KHANIPOVA. R. R. Innovative approaches to teaching and learning English as second and English as foreign language in multilingual education. Humanities \& Social Sciences Reviews, v. 7, n. 6, p. 45-48, 2019.

SOBRÉ-DENTON, M. S.; BARDHAN. N. Cultivating cosmopolitanism for intercultural communication: communicating as a global citizen. London: Routledge, 2013.

SORRELLS, K. Intercultural communication: globalization and social justice. Los Angeles, CA: Sage, 2013.

SWAFFER, J.; ARENS. K. Remapping the foreign language curriculum: an approach through multiple literacies. New York, NY: Modern Language Association, 2005.

TATUM, B. Why are all the black kids sitting together in the cafeteria? New York, NY: Basic Books, 1997.

WEAVER, G. R. Understanding and coping with cross-cultural adjustment stress. Crosscultural orientation. New conceptualizations and applications. Lanham, MD: University Press of America, 1986. 


\section{How to reference this article}

SABIROVA, D. R.; KHANIPOVA, R. R.; SAGITOVA, R. R. English as a tool for crosscultural communication. Rev. EntreLínguas, Araraquara, v. 7, n. esp. 3, e021048, Sep. 2021. e-ISSN: 2447-3529. DOI: https://doi.org/10.29051/el.v7iesp.3.15706

Submitted: $10 / 01 / 2021$

Required revisions: $20 / 03 / 2021$

Approved: 23/06/2021

Published: 01/08/2021 